Filozofski fakultet Pale

Odsjek za psihologiju

Pale, Bosna i Hercegovina

\author{
Andrej Simić \\ Josipa Matošević \\ Univerzitet u Tuzli \\ Filozofski fakultet \\ Odsjek za pedagogiju i psihologiju \\ Tuzla, Bosna i Hercegovina
}

\title{
ZNAČAJ PRIVRŽENOSTI I MOTIVA POSTIGNUĆA PREDANOSTI KARIJERI STUDENATA DRUŠTVENO-HUMANISTIČKIH PROFESIONALNIH USMJERENJA
}

\begin{abstract}
Apstrakt
Karijera predstavlja bitan aspekt u razumijevanju identiteta pojedinca. Koncept kojim se objašnjava važnost karijere u životu pojedinca naziva se karijerna predanost. Cilj ovog rada bio je ispitati doprinos motiva postignuća i dimenzija privrženosti u objašnjavanju karijerne predanosti. Uzorak ovog istraživanja činila su 324 studenta Filozofskog i Edukacijsko-rehabilitacijskog fakulteta u Tuzli. Karijerna predanost je mjerena Career Commitment Scale - CCM (Carson \& Bedeian, 1994) prevedena na bosanski/ hrvatski/srpski jezik. Privrženost je mjerila Inventar iskustava u bliskim odnosima prilagođenom za odnos sa roditeljima (Kamenov i Jelić, 2006). Motiv postignuća utvrđivao se Skalom općeg motiva postignuća (Dunđerović, 2005). Rezultati ispitivanja pokazuju da dimenzije privrženosti i motiv postignuća zajedno objašnjavaju $20 \%$ varijance karijerne predanosti. Motiv postugnuća i dimenzija izbjegavanja značajno su doprinosili objašnjavanju karijerne predanosti, dok dimenzija anksioznosti nije značajan prediktor. Sigurni ispitanici se značajno razlikuju od nesigurnih prema motivu postignuća i karijernoj predanosti. Rezultati se razmatraju u okviru sociokognitivne teorije učenja i karijere.
\end{abstract}

Ključne riječi: karijera, karijerna predanost, motiv postignuća, privrženost, dimenzija izbjegavanja, dimenzija anksioznosti

\section{Uvod}

Izbor budućeg zanimanja predstavlja jednu od najvažnijih prekretnica u životu svakog pojednica. Već nakon završetka osnovne škole mladi ljudi prave određenu vrstu profesionalnog izbora. Čak i u uslovima manje selektivnih i rigidnih obrazovnih sistema (kao što je naš), izbor fakulteta i karijernog usmjerenja znatno utiče na

\footnotetext{
${ }^{1}$ Adresa autora: miroslavgavric@yahoo.com
} 
profesionalni razvoj pojedinca (dalje profesionalno usavršavanje, zaposlenje, plata, motivacija, povrede na radu, izostanci i slično). Dakle, sa individualnog aspekta odabir zanimanja predstavlja jednu od najvažnijih životnih odluka jer ono određuje čitav niz životnih i za sreću relevantnih smjernica (Bogdanović, 2009). Sa druge strane, društvo nastoji da pojedince usmjeri ka onoj radnoj okolini koja najbolje odgovara njihovim sposobnostima, kompetencijama i interesima (Jonhson \& Mortimer, 2002).

U novije vrijeme karijera je prepoznata kao bitno područje u izučavanju čovjekovog razvoja uopće. Karijera se danas odvaja od koncepata radnog mjesta i zanimanja, te predstavlja znatno širi pojam u odnosu na njih (Bahtijarević-Šiber, 1999). Postoji nekoliko pristupa definiranju karijere. Najčešće korištena definicija posmatra karijeru kao skup poslova koje pojedinac obavlja tokom svog životnog vijeka (Bahtijeravić-Šiber, 1999). Problem sa ovom definicijom je u njenoj širini. Zbog navedenog razloga istu je teško operacionalizirati (Carson \& Bedeian, 1994). Uža definicija karijere podrazumijeva identifikaciju i uključivanje pojedinca u svoju profesiju (Hall, 1971). Ova definicija nosi pomalo utopističku konotaciju jer u savremenom svijetu rada veliki broj ljudi obavlja poslove za koje se nisu formalno školovali. Treće shvatanje koncepta karijere nudi Blau (Blau, 1985). Prema ovom autoru karijere su skup vokacija (poziva), dok profesije (zanimanja) predstavljaju samo jedan vid poziva. Ovom definicijom nastoji se naglasiti afinitet, privlačnost i subjektivni „osjećaj poziva“ kojeg pojedinac ima prema svojoj karijeri. Sa druge strane, profesija se posmatra znatno formalnije, pojedinac dobija zvanje profesionalca kada je formalnim putem stekao određene kvalifikacije, vještine i znanja. Dakle, dok je zanimanje jednodimenzionalan i rigidan pojam, karijera je primarno specifično-individualni i fleksibilan pojam. To je razvoj profesionalnog ponašanja u funkciji vremena (Savickas, 2002). Dakle, karijera se odnosi na sve postupke i aktivnosti koje je pojedinac poduzeo tokom svog profesionalnog života. Ona uključuje poslove i pozicije koje je pojedinac obavljao tokon života, njegovo lično usavršavanje i uspjehe na poslu.

\section{Predanost karijeri}

Kao što je već navedeno, karijera predstavlja bitan aspekt u razumijevanju identiteta (Hall, 1971). Što je karijera više centralna u životu pojedinca, više se njegov identitet može razumijeti na osnovu nje. Za objašnjavanje važnosti karijere u cjeloživotnom razvoju koristi se koncept karijerne predanosti. Predanost karijeri najprije se razumjela kao stav kojeg pojedinac ima prema svom pozivu ili profesiji (Blau, 1985). Karson i Bedian (Carson \& Bedeian, 1994) šire ovakvu definiciju predanosti. Prvo, nadovezujući se na Hallov rad (Hall, 1971) karijernu predanost gledaju kao na motivaciju za radom u odabranom pozivu. Dakle, predanost karijeri se više ne shvaća kao stav, ona ima svoju afektivnu i bihevioralnu komponentu. Drugo, u skladu sa Londonovom (London, 1983) teorijom radne motivacije karijerna predanost se posmatra kao multidimenzionalan konstrukt. Njihov model čine tri međusobno povezana faktora predanosti karijeri. Karijerni identitet odnosi se na ostvarivanje bliskog emocionalnog odnosa sa vlastitom karijerom. Planiranje karijere predstav- 
lja određivanje vlastitih razvojnih potreba i postavljanje ciljeva. Posljednji faktor nazvan je karijernom rezilijencijom, a predstavlja suprostavljanje distrakcijama u karijeri tokom nepovoljnih okolnosti.

Postoje konceptualni i empirijski dokazi da je koncept predanosti karijeri odvojen od drugih koncepata predanosti koji se izučavaju u organizacijskoj i vokacijskoj psihologiji (npr. radna, organizacijska, poslovna i slično). Predanost karijeri se posmatra kao predanost vlastitoj vokaciji koja može, ali i ne mora, obuhvaćati poslove koje pojedinac obavlja, organizacije u kojima radi ili radu koji obavlja. Ipak, predanost karijeri je često povezana sa navedenim srodnim konceptima (Carson \& Bedeian, 1994).

\section{Motiv postignuća}

U klasičnim teorijama izbora zanimanja karijerna predanost prepoznata je u okviru personoloških termina. U cjeloživotnom pristupu razvoja karijere Donalda Supera (Super, 1980) pretpostavlja se da pojedinci kroz život razmatraju različita zanimanja, vremenom sužavaju svoje opcije, te biraju ono zanimanje koje će na najbolji način upotpuniti njihovu sliku o sebi. U skladu s tim, ovaj autor posmatra pojedince predane karijeri kao one koji su spremni dugoročno uložiti napor u njihov profesionalni razvoj. Jasno je da Super (1980) smatra da individualne razlike igraju veliku ulogu u odabiru karijere i predanosti istoj.

Jedna od takvih personoloških karakteristika predstavlja motiv postignuća. Motiv postignuća se može razumjeti kao kapacitet za osjećaj ponosa kada se uspjehom u nekoj aktivnosti ostvarilo postignuće (Atkinson, 1964). Preferencija aktivnosti koje pružaju umjeren izazov, užitak u zadacima u kojima je osoba odgovorna za ishod, te preferencija zadataka koje nude povratnu informaciju predstavljaju neke od karakteristika osoba sa visokom potrebom za postignućem (Larsen \& Buss, 2008). Ako gledamo u terminima karijerne predanosti, osobe sa visokim motivom postignuća ulagale bi veći napor u razvoj vlastite karijere, te bi više cijenile uspjeh u profesionalnom životu. U modelu motivacija karijere i postignuća (Farmer, 1985, 1987; Farmer \& Chung, 1995) motiv postignuća i predanost karijeri su usko povezani. Farmer (Farmer, 1985) predlaže da se karijerna motivacija i postignuće mogu podijeliti na tri međusobno povezane sastavnice. Aspiracija predstavlja obrazovni nivo i zanimanje kojem pojedinac teži. Sljedeći faktor u Farmerinom modelu je ovladavanje. Motiv ovladavanja predstavlja težnju da se biraju teži zadaci i perservaciju u njihovom ostvarivanju. Konačno, karijerna motivacija predstavlja stepen u kojem je karijera centralna u životu odrasle osobe. Karijerna motivacija predstavlja predanost dugoročnim ciljevima. U ovom modelu, ovladavanje možemo razumjeti kao Etkinsonov (Atkinson, 1964) motiv postignuća. Nadalje, definicija karijerne motivacije znatno odgovara koncepciji pojma karijerne predanosti koju nude Karson i Bedeian (Carson \& Bedeian, 1994). Dakle, teorijski se može očekivati da su motiv postignuća i predanost karijeri povezani. Naime, ukoliko je pojedinac usmjeren ka potrebi za postignućem moguće je da će imati dugoročnu radnu orijentaciju i plan koji je usmjeren ka njegovoj karijeri (Goulet \& Singh, 2002). 


\section{Privrženost roditeljima i predanost karijeri}

Ključan faktor kod roditeljskih utjecaja na razvoj karijere djeteta, predstavlja odnos roditelj-dijete. Iz navedenih razloga, teorija privrženosti se može iskoristiti za razumijevanje izbora karijere. Rajt i Perone (Wright \& Perrone, 2008) pretpostavljaju da privrženost igra veliku ulogu u razvoju okolinskih i demografskih varijabli koje omogućavaju iskustva učenja. Da bi se uloga ovog koncepta razumjela potrebno je detaljnije razmotriti teoriju privrženosti. Privrženost predstavlja odnos između djeteta i njegovog primarnog skrbnika, najčešće majke. Osim zadovoljavanja fizioloških potreba, odnos sa majkom ima bitan utjecaj na psihički razvoj djeteta. Privrženost se razvija u prvoj godini života, a nakon toga se sa majke širi i na druge bliske osobe (oca, braću, sestre i slično). Bolbi (Bowlby, 1983) definira privrženost kao vid afektivne veze u kojoj se nastoji tražiti i održati blizak odnos sa važnom osobom, naročito u stresnim okolnostima. Prema ovom autoru ovi rani odnosi služe kao radni modeli za formiranje odnosa u odrasloj dobi u smislu nesvjesnog stvaranja očekivanja u odnosima. Na taj način teorija privrženosti služi kao temeljni okvir za razumijevanje velikog broja bliskih socijalnih relacija koje pojedinac ostvaruje tokom svog života (Kamenov i Jelić, 2003).

Tri tipa privrženosti (sigurni, izbjegavajući i anksiozni) koji se formiraju u ranom djetinjstvu uočeni su i u odrasloj dobi. U istraživanjima Hazan i Ševjer (Hazan \& Shaver, 1987) stilovi privrženosti opisani su na sljedeći način:

- Sigurni stil. Osobe sa sigurnim stilom nemaju problema u zbližavanju sa drugim ljudima, te se osjećaju ugodno kada imaju potporu bitnih drugih ili njima daju potporu. Ne brinu da će biti napušteni ili da će se pretjerano zbližiti sa drugom osobom.

- Izbjegavajući stil. Ovim osobama je neugodno zbližiti se sa drugima, ne vjeruju drugima i imaju teškoće u traženju potpore od drugih. Osjećaju neugodu kada njihovi partneri žele biti intimniji u odnosu na intimnost koju oni očekuju.

- Anksiozni stil. Osobe sa anksioznim stilom smatraju da drugi nisu voljni stupiti sa njima u bliske odnose. Brinu se da ih partner ne voli i da će ih napustiti. Partnera ponekad izgube upravo zbog želje da se u potpunosti spoje sa njim.

Bartolomju (Bartholomew, 1990) širi model kojeg su ponudili Hazan i Šejver (Hazan \& Shaver, 1987) i govori o dva podtipa izbjegavajućeg stila. Zaokupljeni stil karakteriše odbrambeno odbijanje i nepostojanje potrebe za bliskim socijalnim kontaktima. Plašljivi stil odnosi se na svjesnu potrebu za socijalnim odnosima inhibiranu strahom od eventualnih negativnih ishoda takvih odnosa.

Način na koji privrženost jača predanost karijeri ogleda se upravo u glavnim karakteristikama sigurnog stila privrženosti. Sigurno privržene osobe karakteriše pojačana sposobnost da istražuju okolinu bez osjećaja straha ili anksioznosti (Bowlby, 1973). Istražujući svoju okolinu, takve osobe će imati priliku da doživljavaju više iskustava za jačanje samoefikasnosti koje bi mogle stvoriti više prilika za učenje (Wright \& Perrone, 2008). Klasične teorije izbora zanimanja i karijere u drugi plan stavljaju okolinske i demografske faktore (Farmer, 1985). Zanemarivanjem okolin- 
skih varijabli proces izbora zanimanja se svodi na kognitivnu procjenu pojedinca koje je zanimanje najbolje za njega poznajući vlastite sposobnosti i interese, te karakteristike okoline. Istraživanja (Goulet \& Singh, 2002; Farmer, 1985, 1987) koja pokazuju da okolinski faktori znatno doprinose izboru zanimanja. Novije teorije izbora zanimanja, naglašavanjem sociokognitivne perspektive i koncepata koji proizlaze iz sociokognitivne teorije učenja (Bandura, 1971), nastoje objasniti kako zajedničko djelovanje personalnih, okolinskih i demografskih varijabli utiče na izbor zanimanja.

Prema sociokognitivnoj teoriji karijere (Lent, Brown, \& Hackett, 1994, 2000) izbor zanimanja predstavlja rezultat kompleksnog djelovanja ličnih dispozicija, sociodemografskih varijabli, te bliskih okolinskih faktora koji u funkciji učenja, percepcije samoefikasnosti i očekivanja ishoda oblikuju interese, ciljeve i u konačnici aktivnost pojedinca prema izboru vlastite karijere. Dalju teorijsku potporu okolinskim faktorima nudi Londonova (London, 1983) teorija radne motivacije. Ovaj autor je ponudio listu od 42 okolinske varijable za koje pretpostavlja da su povezane sa karijernom motivacijom. Londonov teorijski okvir predstavlja temelj za većinu empirijskih studija karijerne predanosti. Konačno, Farmerin model karijerne motivacije i postignuća (Farmer, 1985, 1987; Farmer \& Chung, 1995) pretpostavlja interakciju tri komponente motivacije sa personalnim, okolinskim i sociodemografskim varijablama. Dakle, sa perspektive savremenih teorija karijere, izbor zanimanja ne predstavlja jednostavnu odluku pojedinca donesenu na osnovu njegovog stepena kognitivne zrelosti. Na odluku o izboru zanimanja utječu brojne varijable koje je teško obuhvatiti u većini istraživanja.

Ono što je zajednično navedenim teorijama je naglašavanje važnosti obiteljskog konteksta u procesu izbora zanimanja. Utjecaj roditelja na karijeru njihovog djeteta može se objasniti u okviru sociokognitivne teorije karijere. Naime, roditelji predstavljaju modele pomoću kojih pojedinac uči određeno ponašanje (Bandura, 1971). Posmatranjem drugih pojedinac prvo jača svoju percepciju samoefikasnosti i očekivanja pozitivnih karijernih ishoda (Lent et al., 1994). Roditeljska ponašanja utječu na iskustva učenja djeteta, a sastoje se od sigurne prvrženosti, razvijanja i potkrepljivanja samoefikasnosti i očekivanja ishoda relevantnih za karijeru (Lent et al., 2000). Percepcije samoefikasnosti i pozitivnih ishoda dalje utječu na formiranje interesa, ciljeva i aktivnosti usmjerenih na formiranje karijere (Lent et al., 1994). Dakle, roditelji služe djeci kao modeli o tome koji put u karijeri odabrati, koliko joj biti predan, te koje ishode očekivati u svom profesionalnom životu. Osim važnosti roditelja u formiranju očekivanja djeteta o sebi i okolini, čini se da je roditeljska podrška u izboru zanimanja također bitna. Istraživanja pokazuju da adekvatna roditeljska podrška predstavlja bitan prediktor karijerne predanosti (Farmer, 1987). Prema sociokognitivnoj teoriji karijere samoefikasnost i pozitivni ishodi vezani za karijeru (interesi, ciljevi i karijerna aktivnost) predstavljaju rezultat učenja. Drugim riječima, omogućavanjem pozitivnih iskustava učenja, sigurni stil promoviše visoku samoefikasnost i pozitivne ishode vezane za karijeru.

Zaključno, rani odnos sa roditeljima može znatno determinisati profesionalni život pojedinca. Ukoliko je osoba u odnosu sa roditeljima razvila sigurni stil privrženosti, imala je više prilika za učenje, visoku samoefikasnost i očekivanja od karijere, te na osnovu toga razvila interese, ciljeve i ponašanja koja joj omogućuju predanost i uspjeh u budućoj karijeri. 


\section{Pregled rezultata ranijih istraživanja}

Rezultati istraživanja konzistentno pokazuju da odnos sa roditeljima predstavlja dobar prediktor predanosti karijeri. Utvrđeno je da je sigurna privženost roditeljima povezana sa visokim stepenom karijerne predanosti (Bluestein, Walbridge, Friedlander, \& Palladino, 1991; Scott \& Church, 2001; Zandarelli, Shivy, \& PerroneMcGovern, 2016). U nekim istraživanjima utvrđeno je da je samo privrženost majci dobar prediktor karijerne predanosti (Lee \& Kim, 2015; Rainey \& Borders, 1997), dok su druga pokazala da privrženost ocu predviđa predanost karijeri (O’Brien, Liedman, Tipton, \& Linn, 2000). Nadalje, percepcija roditeljske podrške igra bitnu ulogu u pozitivnim ishodima karijere. Roditeljska podrška statistički značajno predviđa snažnije formiranje karijernog identiteta (Stringer \& Kerpelman, 2010).

Istraživanja usmjerenih na ispitivanje veze između motiva postignuća i karijerne povezanosti ima veoma malo. Rezultati uglavnom ukazuju na pozitivnu, ali slabu povezanost (Goulet \& Singh, 2002; Marshall \& Wijting, 1980). Čini se da, kada se drugi faktori uzmu u obzir, navedena varijabla gubi svoju potenciju (Goulet $\&$ Singh, 2002). Ipak, motiv postignuća kao bitan faktor u objašnjavanju karijerne predanosti ne treba otpisati iz nekoliko razloga. U svom modelu karijerne motivacije i postignuća Farmer (Farmer, 1985) pokazuje da karijernu predanost među velikim brojem varijabli, uspješno predviđaju i sljedeće: stilovi postignuća, atribucije uspjeha zalaganju i vrijednosti postignuća. Nadalje, u navedenom modelu karijerna predanost i motivacija ovladavanja (definirana slično kao motiv postignuća) su usko povezani. Konačno, navedena istraživanja su koristila skraćene verzije instrumenata baziranih na Marejevoj teoriji potreba (Murray, 1938) u kojima motiv postignuća ispituje samo nekoliko čestica. Također, koeficijenti pouzdanosti navedenih instrumenata nisu naročito visoki. Procjene unutrašnje konzistencije Upitnika manifestnih potreba korištenog u istraživanju Gulea i Singha (Goulet \& Singh, 2002) prema Drer i Mo-Dalton (Dreher \& Mau-Dalton, 1983) nisu dovoljno zadovoljavajuće da bi se ovaj instrument koristio u organizacijskom kontekstu. Upitnik samoopisa ličnosti korišten u istraživanju Maršal i Vejting (Marshall \& Wijting, 1980) projektivnog je tipa i bazira se na dopunjavanju rečenica. Njegov alfa koeficijent dobijen na uzorku ženskih studenata iznosi 0.64 (Stein, 1967; prema Marshall i Witjing, 1980).

Dakle, promocijom sigurne prvrženosti između roditelja i djece moguće je razvijati pozitivna karijerna ponašanja i stvarati nove prilike za učenje (Bal \& Barušs, 2001; Larsen \& Buss, 2008). Ovo istraživanje ima za cilj utvrditi doprinos motiva postignuća i stila privrženosti pri objašnjavanju predanosti karijeri.

U skladu sa rezultatima prethodnih istraživanja (Bluestein et al., 1991; Goulet \& Singh, 2002; Marshall \& Wijting, 1980; Scott \& Church, 2001; Zandarelli et al., 2016) može se očekivati da će rani odnosi sa roditeljima i motiv postignuća biti značajni prediktori karijerne predanosti. Motiv postignuća i dimenzije privrženosti (izbjegavanja i anksioznosti) imaće značajan doprinos u objašnjavanju varijance predanosti karijeri.

Model karijerne motivacije i postignuća (Farmer, 1985) daje prednost okolinskim faktorima u objašnjavanju izbora zanimanja. Roditeljski uticaji, poput odnosa roditelj-dijete, predstavljaju jedan od relevanih okolinskih faktora u izboru zanima- 
nja. Rezultati navedenih istraživanja upućuju na snažnu povezanost privrženosti prema roditeljima sa karijernom predanosti, dok je motiv postignuća slabo povezan sa istom. Iz navedenih razloga očekuje se da će dimenzije privrženosti će biti snažniji prediktor predanosti karijeri od motiva postignuća.

Budući da sigurna privrženost u odnosu sa roditeljima predstavlja temelj za razvijanje i potkrepljivane samoefikasnosti i očekivanja pozitivnih karijernih ishoda (Lent et al., 2000), pretpostavlja se da postoje značajne razlike u izraženosti karijerne predanosti između sigurnih i nesigurnih ispitanika.

\section{Metod}

\section{Uzorak i procedura}

Uzorak istraživanja je prigodnog tipa i obuhvatao je 324 studenta druge, treće i četvrte godine jedanaest studijskih odsjeka na Filozofskom i Edukacijsko-rehabilitacijskom fakultetu u Tuzli. Studenti prvih godina nisu uvršteni u istraživanje pod pretpostavkom da nemaju dovoljno iskustva sa različitim aspektima odabranog zanimanja, te se zbog toga ne mogu adekvatno procjenjivati koliko su predani istom. Prosječna dob ispitanika iznosila je 22 godine $(M=21.88 ; S D=1.60)$. Detaljan prikaz uzorka istraživanja prikazan je u Tabeli 1.

Tabela 1

Prosječna dob, spolna struktura i broj ispitanika prema studijskom odsjeku i godini studija

\begin{tabular}{lccccc}
\hline \multirow{2}{*}{ Odsjek } & \multicolumn{3}{c}{ Dob } & \multicolumn{3}{c}{ Spol } & \multirow{2}{*}{$M$} & $S D$ & $\mathrm{M}$ & $\check{Z}$ & $N$ \\
\cline { 2 - 5 } & 21.52 & 1.83 & 10 & 58 & 66 \\
Pedagogija - psihologija & 21.55 & 1.33 & 6 & 16 & 22 \\
Filozofija - sociologija & 21.71 & .92 & 3 & 14 & 17 \\
Razredna nastava & 22.11 & 1.53 & 2 & 16 & 18 \\
Predškolski odgoj & 20.90 & .88 & 7 & 3 & 10 \\
Historija & 22.05 & 1.30 & 14 & 25 & 39 \\
Engleski jezik i književnost & 22.00 & 1.72 & 9 & 24 & 30 \\
Njemački jezik i knjižvenost & 23.00 & 1.03 & 5 & 13 & 18 \\
B/H/S jezik i književnost & 22.66 & 1.68 & 3 & 41 & 44 \\
Socijalni rad & 22.00 & 1.59 & 10 & 24 & 34 \\
Žurnalistika & 20.52 & .75 & 1 & 20 & 21 \\
Logopedija i audiologija & & & & & \\
\hline Godina studija & 20.75 & 1.14 & 27 & 97 & 124 \\
\hline Druga & 21.83 & 1.25 & 21 & 67 & 88 \\
Treća & 23.17 & 1.30 & 22 & 90 & 112 \\
Četvrta & 21.88 & 1.60 & 70 & 254 & 324 \\
\hline$\sum$ & & & & & \\
\hline
\end{tabular}

Ispitivanje je provedeno u maju 2018. godine. Nakon dobijanja dozvole od predmetnog nastavnika, ispitanici su prije zakazanih predavanja popunjavali upitni- 
ke. Ispitivanje je provedeno anonimno i grupno. Ispitanici su bili upoznati sa svrhom i ciljem istraživanja. Popunjavanje upitnika trajalo je 30 minuta.

\section{Instrumenti}

Upitnik karijerne predanosti (Career Commitment Measure-CCM; Carson \& Bedeian, 1994). Ovim instrumentom mjerena je predanost karijeri. Kao što je već rečeno, Karson i Bedeian definiraju karijernu predanost kao multidimenzionalan konstrukt kojeg čine karijerni identitet, planiranje karijere, karijerna rezilijencija. CCM sadrži ukupno 12 stavki. Po četiri stavke mjere tri faktora karijerne predanosti: karijerni identitet, planiranje karijere i karijerna rezulucija. Zadatak ispitanika je da na petostepenoj likertovoj skali $(1$ = uopće se ne slažem / 5 = potpuno se slažem $)$ označi svoj stepen slaganja sa stavkom. Autori izvještavaju da se pouzdanost interne konzistencije (Chrobach's $\alpha$ ) upitnika na studentskoj populaciji kreće između .79 i .85 (Carson \& Bedeian, 1994).

Prevod instrumenta izvršila su 2 govornika ciljnog jezika (bosanski/hrvatski/ srpski jezik) koja fluentno govore engleski jezik. Prevodi su se međusobno usporedili i prilagodili studentskoj populaciji (npr. iz svih stavki je izbačen termin ,posao"). Prevedena verzija instrumenta podvrgnuta je pilot ispitivanju pouzdanosti. Na uzorku od 51 studenta prve i druge godine odsjeka Pedagogija - psihologija u Tuzli utvrđena je pouzdanost u iznosu od $\alpha=.76$, što ukazuje na zadovoljavajuću internu konzistentnost upitnika. Na cijelom uzorku, ovaj upitnik pokazuje, također, zadovoljavajuću pouzdanost merenja $(\alpha=.74)$. Obje vrijednosti se nalaze nešto ispod raspona alfa koeficijenata koje su utvrdili izvorni autori upitnika (Carson \& Bedeian, 1994).

S ciljem provjeravanja faktorske strukture instrumenta, provedena je analiza glavnih komponenti sa oblimin rotacijom (Subotić, 2013). Hornovom paralelnom analizom (Horn, 1965) utvrđena su tri faktora koja bi se trebala zadržati. Faktori sadržinski odgovaraju faktorima koje su autori zadržali u originalnom istraživanju i objašnjavaju ukupno $55 \%$ varijabiliteta stavki instrumenta. Tri stavke su pokazale visoka zasićenja na prvom faktoru koji odgovara karijernom identitetu, dok su po četiri stavke smještene u naredna dva faktora koja odgovaraju karijernom planiranju i karijernoj rezilijeniciji. Jedna stavka nije pokazala zasićenje ni na jednom od navedena tri faktora.

Različit broj stavki u multidimenzionalnim mjerama može utjecati na sam kontekst stavki. Iz navedenog razloga provedena je dodatna analiza glavnih kompotenti kako bi se utvrdila utemeljenost jednodiomenzionalnog rješenja koje sugeriše Blau (Blau, 1985). Jednofaktorsko rješenje objašnjava ukupno 33\% varijabiliteta i svih 12 stavki pokazuju prihvatljiva zasićenja u rasponu od .42 do .68 .

Iako Karson i Bedeian (Carson \& Bedeian, 1994) karijernu predanost shvataju kao multidimenzionalan konstrukt, $\mathrm{u}$ ovom radu uzet će se u obzir jednodimenzionalna konceptualizacija ovog konstrukta koju nudi Blau (Blau, 1985).

Skala općeg motiva postignuća (Dunđerović, 2005). Ovom skalom mjeren je motiv postignuća. Skala ima oblik sumacione skale Likertovog tipa gdje su ispitanici imali mogućnosti da procjene koliko se svaka od 10 tvrdnji odnosi na njih kroz jedan od 5 stepeni (1 - nikad se ne odnosi na mene; 5 - uvijek se odnosi na mene). Metrijske ka- 
rakteristike skale su na zadovoljavajućem nivou (Dunđerović, 2005), u ovom istraživanju provjeravana je pouzdanost skale metodom interne konzistencije i ona iznosi $\alpha=.75$.

Inventar iskustava u bliskim vezama (Experiences in Close Relationship Inventory - ECR; Brennan, Clark, \& Shaver, 1998, adaptirali Kamenov i Jelić, 2003). Koncept privrženosti prema roditeljima mjeren je verzijom ove skale standardiziranom na hrvatskom uzorku. Upitnik se sastoji od 18 stavki Likertovog tipa koje mjere dva faktora privrženosti: anksioznost i izbjegavanje. Cronbachov koeficijent pouzdanosti $(\alpha)$ iznosi za skalu izbjegavanja, .88, a za skalu anksioznosti .83 (Kamenov i Jelić, 2003). Ciljne osobe u ovom istraživanju predstavljaju roditelje ispitanika. Sadržaj ECR procjenjuje se tako što ispitanici imaju u vidu odnos sa oba roditelja. Ukoliko ispitanik nije imao iskustvo sa oba roditelja, dobio je instrukciju mu ciljna osoba predstavlja roditelja koji je odrastao. Na osnovu rezultata, na dvije navedene subskale utvrđuje da li je ispitanik sigurno ili nesigurno prviržen svojim roditeljima. Ukupan rezultat ispitanika na ovoj skali ne predstavlja jednostavnu linearnu kombinaciju njegovog uratka na svim stavkama, nego se posebno zbrajaju bodovi dobijeni na parnim, odnosno neparnim stavkama. Ukupan rezultat ispitanika na neparnim stavkama odnosi se na dimenziju Izbjegavanja, a rezultat ispitanika na parnim stavkama predstavlja dimenziju Anksioznosti. Da bi ispitanik bio sigurno privržen svojim roditeljima potrebno je da postigne rezultat manji od 36 na obje subskale. U suprotnom, riječ je o nesigurno privrženom ispitaniku.

\section{Metode obrade podataka}

U cilju analize prikupljenih podataka korištene su deskriptivne statističke metode, hijerahijska regresijska analiza i t test za nezavisne uzorke.

\section{Rezultati}

Deskriptivni statistici i interkorelacije varijabli ovog istraživanja prikazani su u tabeli 2 .

Tabela 2

Aritmetička sredina, standardna devijacija i korelacije karijerne predanosti, motiva postignuća i dimenzija privrženosti u odnosu sa roditeljima

\begin{tabular}{lccccccccc}
\hline Varijable & $M$ & $S D$ & Max & Min & $S k$ & $K u$ & 1 & 2 & 3 \\
\hline $\begin{array}{l}\text { 1. Karijerna } \\
\text { predanost }\end{array}$ & 43.06 & 7.88 & 19 & 60 & -.28 & -.37 & & & \\
$\begin{array}{l}\text { 2. Motiv } \\
\text { postignuća }\end{array}$ & 38.46 & 5.78 & 22 & 50 & -.33 & -.52 & $.41^{* *}$ & & \\
$\begin{array}{l}\text { 3. Dimenzija } \\
\text { izbjegavanja }\end{array}$ & 24.80 & 10.86 & 9 & 61 & .75 & .19 & $-.31^{* *}$ & $-.386^{* *}$ & \\
$\begin{array}{l}\text { 4. Dimenzija } \\
\text { anksioznosti }\end{array}$ & 20.55 & 8.12 & 9 & 46 & .76 & .10 & $-.18^{* *}$ & $-.211^{* *}$ & $.253^{* *}$ \\
\hline
\end{tabular}

Napomena. Sk - Skjunis (koeficijent asimetrije); Ku - Kurtozis (koeficijent izduženosti) $; * p<.01 ; * p<.05$ 
Analizom skjunisa i kurtozisa utvrđeno je da ta odstupanja od normalne distrubicije na subskalama dimenzija izbjegavanja i anksioznosti nisu naročito visoka. Pozitivni skjunis i kurtozis na obje subskale koji ne prelaze 1.00 ukazuju na blago nadesno zakrivljenu leptokurtičnu distribuciju. Aron, Coups i Aron (Aron, Kups, \& Aron, 1994) sugeriraju da se neparamterijska rješenja primjenjuju isključivo u slučajevima visokih odstupanja od normalne raspodjele, što u ovom radu nije slučaj.

Pošto ispitanici dolaze iz studentske populacije, može se očekivati da ispitanici imaju formirane pozitivne stavove, planove i očekivanja o vlastitoj karijeri (Lent et al., 2000; Gottredson, 1981), te su motivirani osjećajem ponosa za postizanje uspjeha u studentskim aktivnotima (Atkinson, 1964). Sa druge strane, očekivani su i niski skorovi na dimenziji izbjegavanja $(M=24.80 ; S D=10.86)$ i dimenziji anksioznosti $(M=20.55 ; S D=8.12)$ u odnosu sa roditeljima. Ispitanici pripadaju normalnoj, zdravoj populaciji, pa se može očekivati niska zastupljenost obrazaca ponašanja koji ukazuju ne nesigurne aspekte privrženosti u odnosu sa roditeljima.

Analizom korelacijske matrice varijabli istraživanja utvrđene su umjerene, pozitivne i statistički značajne korelacije motiva postignuća sa karijernom predanosti. Nadalje, dimenzija izbjegavanja je umjereno i negativno povezana sa karijernom predanosti. Dimenzija anksioznosti je u niskoj korelaciji sa karijernom predanosti $(r=-.18)$.

\section{Motiv postignuća, dimenzije izbjegavanja i anksioznosti u odnosu sa roditeljima kao prediktori karijerne predanosti}

U svrhu ispitivanja prve hipoteze provedena je hijerahijska multipla regresijska analiza. Analizom prediktorskih korelacija nisu utvrđene visoke povezanosti među istima $(\mathrm{r}<.70)$, te nema razloga sumnjati na prisustvo multikolinearnosti. Analizom ekstremnih vrijednosti i reziduala, utvrđeno je nepostojanje problematičnih slučajeva, te su zadovoljene pretpostavke o homoscedastičnosti. S obzirom na prirodu navedenih varijabli istraživanja, te postavljenih hipoteza motiv postignuća, dimenzije izbjegavanja i anksioznosti u odnosu sa roditeljima su u model uvršetni kao prediktorske varijable, dok je karijerna predanost predstavljala kriterijsku varijablu.

Provedena je multipla hijerahijska regresijska analiza iz dva koraka. Dimenzije privrženosti prema roditeljima uvrštene su u prvom koraku, dok je motiv postignuća uvršten u drugom. Redoslijed uključivanja varijabli je hronološki opravdan ako se uzmu u obzir karakteristike razvoja izbora zanimanja koji nudi sociokognitivna teorija Lenta i suradnika (Lent et al., 1994, 2000). Naime, kako je već navedeno, privrženost prema roditeljima je relevantna od najranije dobi i predstavlja osnovu za razvijanje pozitivnih očekivanja i samoefikasnosti o određenom karijernom području. Sa druge strane, visok motiv postignuća javlja se tek u situacijama kada je dijete imalo priliku da doživi uspjeh u nekoj aktivnosti (u ovom slučaju aktivnosti povezanoj sa izborom karijere).

Rezultati hijerahijske regresijske analize prikazani su u Tabeli 3. 
Tabela 3

Pregled rezultata hijerahijske multiple regresijske analize u objašnjavanju doprinosa motiva postignuća $i$ dimenzija privrženosti u objašnjavanju karijerne predanost $i$

\begin{tabular}{|c|c|c|c|c|c|c|c|c|}
\hline & Varijable & $B$ & $S E B$ & $\beta$ & $t$ & $R$ & $R^{2}$ & $\Delta R^{2}$ \\
\hline \multirow{3}{*}{ Korak 1} & & & & & & .33 & $.11 * *$ & $.11 * *$ \\
\hline & $\begin{array}{l}\text { Dimenzija } \\
\text { izbjegavanja }\end{array}$ & -.20 & .04 & $-.28 * *$ & $-5.28 * *$ & \multirow{6}{*}{.45} & \multirow{6}{*}{$.20 * *$} & \multirow{6}{*}{$.09 * *$} \\
\hline & $\begin{array}{l}\text { Dimenzija } \\
\text { anksioznosti }\end{array}$ & -.10 & .05 & -.10 & -1.94 & & & \\
\hline \multirow{4}{*}{ Korak 2} & & & & & & & & \\
\hline & $\begin{array}{l}\text { Dimenzija } \\
\text { izbjegavanja }\end{array}$ & -.12 & .04 & $-.17 * *$ & $-3.09 * *$ & & & \\
\hline & $\begin{array}{l}\text { Dimenzija } \\
\text { anksioznosti }\end{array}$ & -.06 & .05 & -.07 & -1.27 & & & \\
\hline & $\begin{array}{l}\text { Motiv } \\
\text { postignuća }\end{array}$ & .45 & .07 & $.33 * *$ & $6.02 * *$ & & & \\
\hline
\end{tabular}

Napomjena. $R_{\text {adj }}$ za korak $1=.10 ; R_{\text {adj }}$ za korak $2=.19 ; * * p<.01 ; * p<.05$

Rezultati iz tabele 3 ukazuju da dimenzije privrženosti prema roditeljima značajno doprinosti objašnjavanju karijerne predanosti studenata. Dimenzije zajedno objašnjavaju $11 \%$ varijabiliteta predanosti karijeri, $R^{2}=.11, F(2,321)=19.72, p<$ .01. Uključivanjem motiva postignuća u model, dodatno je objašnjeno $9 \%$ varijabiliteta karijerne predanosti $R^{2}=.20, F(3,320)=26.66, p<.01$. Navedena promjena u $R^{2}$ je bila statistički značajna, $\Delta R^{2}=.09, F(1,320)=36.21, p<.01$. Kada su sve varijable uvrštene u model u koraku 2 , značajan pojedinačni doprinos daju motiv postignuća $(\beta=.33, p<.01)$ i dimenzija izbjegavanja $(\beta=-.17, p<.01)$. Usporedbom $\beta$ koeficijenata može se zaključiti da je motiv postignuća snažniji prediktor karijerne predanosti od dimenzije izbjegavanja.

\section{Karijerna predanost sigurnih i nesigurnih ispitanika}

Za testiranje druge hipoteze proveden je t-test za nezavisne uzorke u kojem je testirana statistička značajnost razlika karijernoj prednosti kod sigurnih i nesigurnih studenata. Zbog prirode distribucije tipova privrženosti u normalnoj populaciji (nesigurni tipovi su slabo reprezentirani) prema kriterijima koje nude Kamenov i Jelić (2005) formirane su dvije grupe ispitanika: sigurni ispitanici i grupa nesigurnih ispitanika koje uključuje tri navedena tipa nesigurne privrženosti. Ako bi ispitanik ostvario skor manji od 36 na skalama izbjegavanja i anksioznosti bio bi uvršten u grupu sigurno privrženih ispitanika, dok bi u ostalim slučajevima pripadao grupi nesigurnih.

Levenov test ukazuje da je pretpostavka o jednakosti varijanci među grupama zadovoljena $(F=.19, \mathrm{p}>.05)$, pa se interpretaciji rezultata t-testa pristupilo bez korigovanja stupnjeva slobode. Kod sigurno privrženih ispitanika utvrđena je izraženija 
karijerna pripadnost $(M=44.21, S D=7.46)$ u odnosu na nesigurno privržene $(M=$ $38.46, S D=7.89), t(322)=5.49, p<.01, \Omega^{2}=.08$. Vrijednost $\Omega^{2}$ ukazuje da se $8 \%$ varijabiliteta karijerne predanosti može objasniti razlikama između sigurnih i nesigurnih ispitanika. Prema Koenovim kriterijima (Cohen, 1988) riječ je o umjerenom efektu. Dakle, sigurni privrženi studenti su više predani vlastitoj karijeri u odnosu na nesigurne.

\section{Diskusija}

Prva hipoteza istraživanja pretpostavljala je da je motiv postignuća značajan prediktor karijerne predanosti. Rezultati su pokazali da motiv postignuća značajno doprinosi u objašnjavanju varijance karijerne predanosti. Iako prethodni radovi nisu identificirali motiv postignuća kao relevantan prediktor karijerne predanosti (Goulet \& Singh, 2002; Marshall \& Wijting, 1980), kao što je već navedeno, motiv postignuća se u navedenim istraživanjima utvrđivao pomoću instrumenata upitnih psihometrijskih karakteristika koji su uz motiv postignuća mjerili i neke druge psihološke motive. Nadalje, rezultati ovog istraživanja imaju značajnu teorijsku potporu. Farmer (1985) u svom modelu karijerne motivacije predlaže povezanost karijerne predanosti sa varijablama koje odražavaju Atkinsonovu (Atkinson, 1964) definiciju motiva postignuća: stilovi postignuća, atribucije uspjeha zalaganju i vrijednosti postignuća. Dakle, studenti, koji više vrednuju postignuće, doživljavaju zadovoljstvo kada uspiju u nekoj aktivnosti, preferiraju izazovne zadatke i cijene povratnu informaciju, te će se intenzivnije identificirati sa vlastitom karijerom. Također, takve osobe će uspješnije planirati razvoj vlastite karijere i suočavati se sa svim nevoljama na koje će nailaziti u svom profesionalnom životu. Za očekivati je da će studenti sa visokim motivom postignuća duže istrajavati u svojim karijernim ciljevima, te ulagati veći napor u profesionalni razvoj i napredovanje.

Nadalje, pretpostavljalo se da će dimenzije privrženosti u odnosu sa roditeljima dati značajan doprinos u objašnjavanju karijerne predanosti. Rezultati ovog istraživanja pokazuju da je samo dimenzija izbjegavanja značajan prediktor karijerne predanosti. Jedan od razloga zašto dimenzija anksioznosti ne doprinosi značajno u objašnjavanju predanosti karijeri može se pronaći u karakteristikama uzorka istraživanja. Naime, kod ispitanika u studentskoj dobi manje je prisutan strah od napuštanja članova obitelji, dok je izraženija želja za izbjegavanjem i osamostaljivanjem (Kamenov i Jelić, 2006). Dakle, studenti koji osjećaju neugodu prilikom bliskosti i ovisnosti (Fraley \& Shaver, 2000) u odnosu sa svojim roditeljima vjerovatno će biti manje predani vlastitoj karijeri. Sa druge strane, studenti koji ne doživljavaju negativne emocije kada su bliski sa roditeljima će pokazivati izraženiju karijernu predanost. Ovaj nalaz može se interpretirati u okviru socio-kognitivne teorije izbora zanimanja (Lent et al., 1994, 2000). Pod pretpostavkom da rani odnos sa roditeljima predstavlja radni model za formiranje ostalih odnosa u kasnijem životu djeteta (Bowlby, 1983) za očekivati je da će osobe koje su usvojile izbjegavajuće obrasce ponašanja u djetinjstvu ulaziti u manje bliskih odnosa u kasnijoj dobi. Zbog ne- 
dovoljnog broja relevantnih socijalnih relacija, takve osobe neće dobijati dovoljno povratnih informacija (prilika za učenje) iz okoline, te neće imati potrebnu osnovu za razvijanje samoefikasnost (Bandura, 1971) i pozitivnih očekivanja o svom budućem zanimanju (Atkinson, 1957). Niska samoefikasnost rezultirala bi neuspjehom u formiranju konkretnih profesionalnih interesa i ciljeva, te poduzimanju ponašanja da se oni ostvare (Lent et al., 1994).

Nadalje, uloga roditelja kao modela u formiranju visoke karijerne predanosti se ne smije zanemariti. U odnosu roditelja i djeteta koje karakterište dimenzija izbjegavanja nema dovoljno pozitivnih iskustava učenja koji bi mogli facilitirati razvoj visoke samoefikasnosti i pozitivnih očekivanja glede odabranog zanimanja. Drugim riječima, osobe, koje rjeđe osjećaju neugodu u odnosu sa svojim roditeljima, zbog više prilika za razvijanje samoefikasnosti i pozitivnih očekivanja formiraće konkretnije interese i ciljeve, te se upuštati u ponašanja koja bi ih mogla ostvariti. Takve osobe karakteriše visoka karijerna predanost.

U ovom istraživanju utvrđeno je da motiv postignuća daje značajniji doprinos od dimenzija privrženosti u objašnjavanju varijance karijerne predanosti. Ovi rezultati su pomalo iznenađujući jer većina modela karijerne motivacije (Farmer, 1985, 1987; Goulet \& Singh, 2002) daje prednost okolinskim faktorima u odnosu na personalne dispozicije u formiranju visoke karijerne predanosti. Ipak, u obzir treba uzeti i statistički značajne, umjerene korelacije motiva postignuća sa dimenzijama privrženosti. Riječ je o negativnom odnosu ova tri konstrukta, gdje visok motiv postignuća prate niski rezultati na dimenzijama izbjegavanja i anksioznosti. Moguće je da sigurna privrženost predstavlja osnovu za formiranje visokog motiva postignuća. Sigurno privržene osobe bez straha ili anksioznosti istražuju svoju okolinu (Bowlby, 1973), te stoga imaju više prilika za doživljavanje pozitivnih životnih iskustava koja jačaju njihov motiv postignuća. Pošto je riječ o dobi ispitanika u kojoj će se personalne dispozicije poput motiva postignuća relativno malo mijenjati, može se pretpostaviti da je visok motiv postignuća direktan rezultat manjeg osjećaja neugode i straha od napuštanja u odnosu sa svojim roditeljima.

Posljednja hipoteza istraživanja podrazumijevala je ispitivanje razlika između sigurnih i nesigurnih ispitanika prema predanosti vlastitoj karijeri. Rezultati ispitivanja pokazuju da sigurni ispitanici imaju izraženiju karijernu predanost u odnosu na nesigurne. Rezultati ispitivanja potvrđuju neke prethodne nalaze (Bluestein et al., 1991; Scott \& Church, 2001; Zandarelli et al., 2016) u kojima je također utvrđeno da se sigurni ispitanici razlikuju od nesigurnih na osnovu karijerne predanosti. Dakle, sigurni ispitanici bolje planiraju i suočavaju se sa karijernim izazovima, te se više identifikuju sa svojom karijerom (Carson \& Bedeian, 1994). Također, sigurni ispitanici doživljavaju više zadovoljstva kada postignu uspjeh u nekoj aktivnosti. Za očekivati je da sigurni pojedinci doživavljavaju više pozitivnih iskustava za jačanje samoefikasnosti (Wright \& Perrone, 2008).

Izraženiju karijernu predanost sigurnih studenata moguće je objasniti njihovim ranim odnosom sa roditeljima. Elliot i Reis (2003) pretpostavljaju da će djeca sa sigurnom privrženošću vjerovatnije istraživati vlastitu okolinu i na taj način učiti nove vještine. Dok odrastaju u takvim okolinskim uvjetima, naučena samoefikasnost 
dovodi do veće motivacije za postignućem i vrednovanja vlastitih kompetencija. Uloga roditelja u razvijanju pozitivnih stavova prema vlasitoj karijeri se ne smije zanemariti. Prvo, sigurnoj djeci roditelji češće facilitiraju nezavisnost i od njih traže samostalna ponašanja (Bal \& Barušs, 2001). Treniranje djeteta da bude nezavisno u životu promiče osjećaj efikasnosti i samopouzdanja kod djeteta (Larsen \& Buss, 2008). Drugi način na koji roditelji mogu jačati motiv postignuća (a samim tim i pozitivna očekivanja od karijere) svog djeteta je postavljanjem visokih standarda (Heckhausen, 1982, prema Larsen \& Buss, 2008) koji pružaju izazov za dijete i osjećaj zadovoljstva kada se oni dostignu. Može se očekivati da su roditelji sigurno privržene djece češće postavljali visoke, ali ostvarive standarde i pružali potporu u njihovom ostvarivanju. Nadalje, kada je cilj postignut moguće je da su i češće nagrađivali dijete. Djeca koja su u svojoj okolini imala veliki broj pozitivnih potkrepljenja imaju izraženiji motiv postignuća u odnosu na drugu djecu (Crandall, Katowsky, \& Pretson, 1960).

Dakle, roditelji, pružanjem prilika za učenje jačaju osjećaj djeteta da može uspjeti u nekoj aktivnosti, odnosno u odabranom zanimanju i kasnije karijeri. Takva djeca kasnije izrastaju u odrasle ljude za jasno diferenciranim profesionalnim interesima, ciljevima i ponašanjima.

Rezultati ovog istraživanja sa sobom nose nekoliko bitnih implikacija. Promovisanje sigurne privrženosti može biti temelj za razvijanje visokog motiva postignuća i karijerne predanosti. Nadalje, kontinuirano poticanje razvoja samog motiva postignuća od ranog djetinjstva može značajno doprinijeti većoj identifikaciji sa vlastitom karijerom, boljem planiranju iste, te uspješnijem suočavanju sa svim problemima i nedaćama sa kojima se pojedinac suočava u svom profesionalnom životu.

$\mathrm{Na}$ kraju, potrebno se osvrnuti i na nedostatke ovog istraživanja. Prvi nedostatak može se pronaći u karakteristikama samog uzorka. Pošto je riječ o prigodnom tipu, ispitanici nisu ujednačeni prema spolu (znatno je više ispitanica) i još važnije prema tipovima privrženosti (sigurni tipovi dominiraju u općoj populaciji). Drugo, model koji uključuje dimenzije privrženosti prema roditeljima i motiv postignuća objašnjava samo $20 \%$ varijance karijerne predanosti. Moguće je da karijernu predanost predviđaju i neki drugi dispozicionalni i okolinski faktori koji u ovom radu nisu obuhvaćeni. Treće, pošto je riječ o transverzalnom istraživanju kauzalni zaključci o odnosima između varijabli istraživanja nisu mogući. Eksperimentalne i longitudinalne studije su potrebne kako bi se razumjeli i utvrdili kauzalni odnosi između navedenih konstrukata. Četvrto, podaci su prikupljeni metodom samoprocjene što je moglo dovesti do davanja socijalno prihvatljivih odgovora. Peto, stavke koje su mjerile karijernu predanost prevedene su na ciljni jezik i prilagođene subkulturi studenata. Posljednje, neadekvatan prevod i neadekvatna formulacija stavki mogle su utjecati na rezultate ovog istraživanja. Potrebno je ispitati odnos između varijabli istraživanja korištenjem psihometrijski valjanijih i pouzdanijih instrumenata. Konačno, karijerna predanost je u ovom radu tretirana kao jednodimenzionalni konstrukt. Moguće je da bi se dobila dodatna saznanja o odnosu ove varijable sa motivom postignuća i privrženosti prema roditeljima, ako se karijerna predanost tretira kao multidimenzionalan konstrukt (Carson \& Bedeian, 1994). 
Iz navedenih razloga eventualna preporuka za buduća istraživanja odnosi se na ispitivanje doprinosa drugih varijabli za koje pojedini autori (Hall, 1971; Farmer, 1985, 1987) pretpostavljaju da bi mogli biti značajni prediktori karijerne predanosti. Nadalje, buduća istraživanja treba usmjeriti na primjenu eksperimentalnih i longitudinalnih nacrta uz kompleksniju operacionalizaciju varijabli istraživanja.

\section{Zaključak}

Ovaj rad bavio se odnosom dimenzija privrženosti sa roditeljima, te motiva postignuća sa karijernom predanošću. Utvrđeno je da su dimenzija izbjegavanja i motiv postignuća značajni prediktori predanosti karijeri studenata. Nadalje, sigurni studenti imaju izraženiji motiv postignuća i predanosti karijeri u odnosu na nesigurne. Rezultati istraživanja potvrđuju važnost okolinskih faktora u podupiranju i razvoju personoloških karakteristika bitnih za adekvatan izbor zanimanja i pozitivne karijerne ishode.

\section{Reference}

Aron, A., Coups, E. J., \& Aron, E. N. (2013). Statistics for Psychology (6th ed.). Boston, NJ: Pearson.

Atkinson, J. W. (1957). Motivational determinants of risk-taking behavior. Psychological Review, 64(6, Pt.1), 359-372. doi: 10.1037/h0043445

Atkinson, J. W. (1964). An introduction to motivation. Princeton, NJ: Van Nostrand.

Bahtijerević-Šiber, F. (1999). Menadžment ljudskih potencijala. Zagreb: Golden Marketing.

Bal, M., \& Barušs, I. (2011). Perceived parental attachment and achievement motivation. Psychological Reports, 109(3), 940-948. doi: 10.2466/09.10.21.PR0.109.6.940-948

Bandura, A. (1971). Social learning theory. New York, NY: General Learning Press.

Bartholomew, K. (1990). Avoidance of intimacy: An attachment perspective. Journal of Social and Personal Relationships, 7(2), 147-178. doi: 10.1177/0265407590072001

Blau, G. J. (1985). The measurement and prediction of career commitment. Journal of Occupational Psychology, 58(4), 277-288. doi: 10.1111/j.2044-8325.1985.tb00201.x

Blustein, D. L., Walbridge, M. M., Friedlander, M. L., \& Palladino D. E. (1991). Contributions of psychological separation and parental attachment to the career development process. Journal of Counseling Psychology, 38(1), 39-50.

Bogdanović, M. (2009). Prilog primarnoj profesionalnoj orijentaciji: kako do bolje povezanosti sa stvarnim životom? Napredak, 150(2), 224-249.

Bowlby, J. (1973). Attachment and Loss, Vol. 2: Separation: Anxiety and Anger. New York, NY: Basic Books.

Bowlby, J. (1983). Attachment and Loss, Vol. 1, Attachment (2nd ed.). NewYork, NY: Basic Books. 
Brennan, K. A., Clark, C. L., \& Shaver, P. R. (1998). Self-report measurement of adult attachment: An integrative overview. In J. A. Simpson \& W. S. Rholes (Eds.), Attachment theory and close relationships (pp. 46-76). New York, NY: Guilford PreSS.

Carson, K. D., \& Bedeian, A. G. (1994). Career commitment: Construction of a measure and examination of its psychometric properties. Journal of Vocational Behavior, 44(3), 237-262. doi: 10.1006/jvbe.1994.1017

Crandall, V., Katkovsky, W., \& Preston, A. (1960). A conceptual formulation for some research on children's achievement development. Child Development, 31(4), 787-797.

Cohen, J. (1988). Statistical Power Analysis for the Behavioral Sciences. Hillsdale, NJ: L. Erlbaum Associates

Dreher, D. F., \& Dalton, R. R. (1983). A note on the internal consistency of the Manifest Needs Questionnaire. Journal of Applied Psychology, 68(1), 194-196. doi: 10.1037/0021-9010.68.1.194

Dunđerović, R. (2005). Osnovi psihologije menadžmenta. Novi Sad: Fakultet za menadžment.

Elliot, A. J., \& Reis, H. T. (2003). Attachment and exploration in adulthood. Journal of Personality and Social Psychology, 85(2), 317-331. doi: 10.1080/00207594.2012.658402

Farmer, H. S., \& Chung, B. Y. (1995). Variables related to career commitment, mastery motivation, and level of career aspiration among college students. Journal of Career Development, 21(4), 265-278. doi: 10.1177/089484539502100401

Farmer, H. S. (1985). Model of career and achievement motivation for women and men. Journal of Counseling Psychology, 32(3), 363-390. doi: 10.1037/0022-0167.32.3.363

Farmer, H. S. (1987). A multivariate model for explaining gender differences in career and achievement motivation. Educational Researcher, 16(2), 5-9. doi: 10.3102/0013189X016002005

Fraley, R. C., \& Shaver, P. R. (2000). Adult romantic attachment: Theoretical developments, emerging controversies, and unanswered questions, Review of General Psychology, 4(2), 132-154. doi: 10.1037//1089-2680.4.2.132

Gottfredson, L. S. (1981). Circumscription and compromise: A developmental theory of occupational aspirations. Journal of Counseling Psychology, 28(6), 545-579.

Goulet, L. R., \& Singh, P. (2002). Career Commitment: A Reexamination and an extension. Journal of Vocational Behavior, 61(1), 73-91. doi: 10.1006/jvbe.2001.1844

Hall, D. T. (1971). A theoretical model of career subidentity development in organizational settings. Organizational Behavior and Human Performance, 6(1), 50-76. doi: 10.1016/0030-5073(71)90005-5

Hazan, C., \& Shaver, P. (1987). Romantic love conceptualized as an attachment process. Journal of Personality and Social Psychology, 52(3), 511-524.

Horn, J. L. (1965). A rationale and test for the number offactors in factor analysis. Psychometrika, 30(2), 179-185. doi: 10.1007/BF02289447

Kamenov, Ž. i Jelić, M. (2003). Validacija instrumenta za mjerenje privrženosti u različitim vrstama bliskih odnosa: Modifikacija Brennanova Inventara iskustava u bliskim vezama. Suvremena psihologija, 6(1), 73-91. 
Johnson, M. K., \& Mortimer, J. T. (2002). Career choice and development from a sociological perspective. In D. Brown \& Associates (Eds.), Career Choice and Development (pp. 37-85). San Francisco, SA: Jossey-Bass.

Larsen, R. J., \& Buss, D. M. (2008). Psihologija ličnosti. Jastrebarsko: Naklada slap. (hrvatsko izdanje)

Lee, J., \& Kim, M. (2015). Parental attachment, career decision self-efficacy, and commitment to the career choice among korean college students. Journal of Asia Pacific Counseling, 5(1), 39-52. doi: 10.18401/2015.5.1.3.

Lent, R. W., Brown, S. D., \& Hackett, G. (1994). Toward a unifying social cognitive theory of career and academic interest, choice, and performance. Journal of Vocational Beheavior, 45(1), 79-122. doi: 10.1006/jvbe.1994.1027

Lent, R. W., Brown, S. D., \& Hackett, G. (2000). Contextual supports and barriers to career choice: A social cognitive analysis. Journal of Counseling Psychology, 47(1), 36-49. doi: http://dx.doi.org/10.1037/0022-0167.47.1.36

London, M. (1983). Toward a theory of career motivation. Academy of Managment Review, 8(4), 620-630. doi: 10.2307/258263

Marshall, S. J., \& Wijting, J. P. (1980). Relationships of achievement motivation and sexrole identity to college women's career orientation. Journal of Vocational Behavior, 16(3), 299-311. doi: 10.1016/0001-8791(80)90057-3

Murray, H. A. (1938). Explorations in Personality. New York, NY: Oxford University Press.

O’Brien K. M., Firedman, S. M., Tipton, L. C., \& Linn, S. G. (2000). Attachment, separation, and women's vocational development: A longitudinal analysis. Journal of Counseling Psychology, 47(3), 301-315. doi: 10.1037/0022-0167.47.3.301

Rainey, L. M., \& Borders, L. A. (1997). Influential factors in career orientation and career aspiration of early adolescent girls. Journal of Counseling Psychology, 44(2), 160-172. doi: 10.1037//0022-0167.44.2.160

Savickas, M. L. (2002). Career construction: A developmental theory of vocational behavior. In D. Brown \& Associates (Eds.), Career Choice and Development (4th ed., pp. 149-205). New York, NY: Wiley.

Scott, D. J., \& Church, A. T. (2001). Separation/attachment theory and career decidedness and commitment: Effects of parental divorce. Journal of Vocational Behavior, 58(3), 328-347. doi: 10.1006/jvbe.2000.1769

Stringer, K. J., \& Kerpelman, J. L. (2010). Career identity development in college students: Decision making, parental support, and work experience. Identity: An International Journal of Theory and Research, 10(3), 181-200. doi: 10.1080/15283488.2010.496102

Subotić, S. (2013). Pregled metoda za utvrđivanje broja faktora i komponenti (u EFA i PCA). Primenjena psihologija, 6(3), 203-229. doi: 10.19090/pp.2013.3.203-229

Super, D. E. (1980) A life-span, life-space approach to career development. Journal of Vocational Behavior, 16(3), 282-298. doi: 10.1016/0001-8791(80)90056-1

Wright, S. L., \& Perrone, K. M. (2008). The impact of attachment on career-related variables: A review of the literature and proposed theoretical framework to guide future research. Journal of Career Development, 35(2), 87-106. doi: 10.1177/0894845308325643

Zandarelli, G., Shivy, V. A., \& Perrone-McGovern, K. M. (2016). Predicting behavioral career commitment of college students with attachment and separation relationships. Journal of Employment Counseling, 53(4), 162-173. doi: 10.1002/joec.12041 


\title{
Miroslav Gavrić2
}

University of East Sarajevo

Faculty of Philosophy Pale

Department of Psychology

Pale, Bosnia and Herzegovina

\author{
Andrej Simić \\ Josipa Matošević \\ University of Tuzla \\ Faculty of Philosophy \\ Department of Pedagogy and Psychology \\ Tuzla, Bosnia and Herzegovina
}

\section{IMPORTANCE OF ATTACHMENT AND ACHIEVEMENT MOTIVE FOR THE CAREER COMMITMENT OF HUMANITIES AND SOCIAL SCIENCES STUDENTS}

\begin{abstract}
Career is an important aspect when it comes to understanding an indivudual's identity. The concept which explains the importance of career in one's life is called career commitment. The aim of this paper was to examine the contribution of the achievement motive and attachment dimensions in explaining carrer commitment. The research sample consistend of 324 students of Faculty of Philosohpy and Educational-rehabilitational Faculty in Tuzla. Career Commitment was measured with Career Commitment Scale - CCM (Carson \& Bedeian, 1984) which was translated on the bosnian/croatian/serbian language. Parent attachment was measured with the Experiences in close relationship intvenory that was modified to asses the relationship with parents (Kamenov and Jelić. 2006). The achievement motive was assed with the General achievement motive scale (Dunđerović, 2005). The results show that attachment dimensions and the achievement motive explain $20 \%$ od the carreer commitment variance. The Achievement motive and avoidance dimension contribute significantly in explaining career commitment, while the anxiety dimensions was not an signitifacnt predictor. Safely attached respondents significantly differ from unsafe respondents when it comes to the acievement motive and carrer commitment. The results are disscused in the framework of the social-cognitive theory of learning and carrer.
\end{abstract}

Keywords: carrer, career commitment, achievement motive, attachment, avodiance dimension, anxiety dimension

Primljeno: 15. 06. 2019.

Primljena korekcija: 09. 09. 2019.

Prihvaćeno za objavljivanje: 12. 09. 2019.

${ }^{2}$ Corresponding author email: miroslavgavric@yahoo.com 